In offering to serve as host to the Congress, the U S Government has been influenced by the widespread interest and support of leading forestry groups in the country and the readiness of the Forest Service of the Department of Agriculture to assume leadership in helping to develop the necessary plans and arrangements for the Congress. This support derives in part from the feeling that, since previous Congresses have been held in Europe and Asia, it is timely to hold a Congress in the Western Hemisphere. The site proposed is the State of Washington or Oregon, in the Pacific Northwest, which is outstanding for its great forest wealth, complex and variety of forest industries, national forests, research centers, forest schools and other forest institutions. The regional tours and field excursions to be arranged will provide an unparalleled opportunity to observe at first hand the advance of technological development that has taken place in the United States in recent years.

Past World Forestry Congresses have been held in Rome in 1926, in Budapest in 1936, in Helsinki 1949 and in India 1954. The meetings are composed of individuals rather than of government representatives and the responsibility for the technical and financial arrangements rests with the host country.

\title{
Official Opening of Alberta's First Pulp Mill
}

Officials of the North Western Pulp \& Power Ltd., combining Hinton's opening celebration with a Timber festival, staged an impressive array of events to mark an important occasion for the Company and the Province of Alberta.

Eric Huestis, Director of Forestry; R. D. Loomis, Forest Surveys Chief; Herb Hall, Assistant Director; Charles Jackson, Forest Management; and Superintendent of Protection, T. R. Hammer, representing the province of Alberta, attended the official opening of the mill.

\section{Ontario Professional Foresters Meet}

The first general meeting of the Ontario Professional Foresters Association, attended by 150 foresters from different parts of Ontario, was held at the Empire Hotel, North Bay, on September 6th and 7th.

This Association, established under an act passed at the last session of the Ontario Legislature, has a membership representing all fields of activity connected with the protection, management, and administration, of the public and private forests of the Province.

At the inaugural dinner of the Association the guest speaker was Mr. James Vance, past president of the Engineering Institute of Canada, Chairman of the Canadian Forestry Association, and a member of the Ontario Water Resources Commission.

It is of interest to note that the O.P.F.A., which gives legal recognition to the profession of forestry in Ontario, has been formed just fifty years after the University of Toronto Forestry School was established. 